
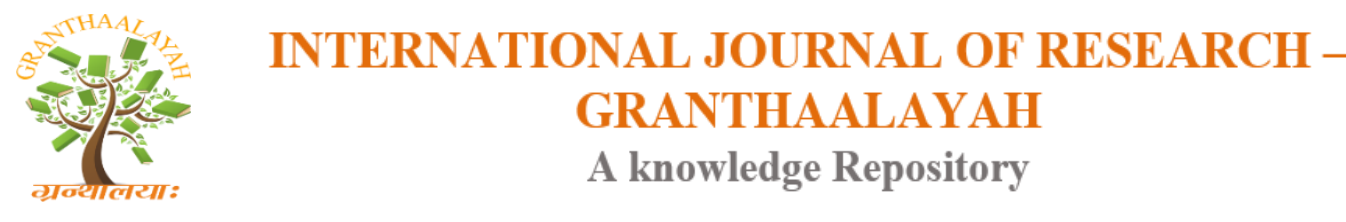

Management

\title{
ACADEMIC STAFF JOB EMBEDDEDNESS: MODEL DIMENSIONALITY AND VALIDATION IN TANZANIA'S UNIVERSITIES
}

\author{
Silver J. Hokororo ${ }^{*}$, Ernest Kitindi ${ }^{2}$, Francis Michael ${ }^{3}$ \\ ${ }^{* 1}$ Department of Business Management, Sokoine University of Agriculture, Tanzania \\ ${ }^{2}$ Department of Accounting, University of Dar es Salaam, Tanzania \\ ${ }^{3}$ Department of General Management, University of Dar es Salaam, Tanzania
}

\begin{abstract}
Universities in Tanzania as many others in Africa and the globe are faced with the challenge of retaining their academic staff. This study examined the dimensionality and generalization of Job Embeddedness Theory, a promising perspective for understanding employee retention, in the context of academic staff in Tanzania's universities. A survey of 314 members of academic staff from 2 Public Universities and 3 Private Universities was conducted, and Exploratory Factor Analysis (EFA) and Split Sample Cross Validation were used in determining the appropriate dimensionality and generalizability of Job Embeddedness Model in the context of study, respectively. Results indicated that that job embeddedness in the context of academic staff in Tanzania's universities is a seven factors model. The results also indicate that seven variables out of 30 in the model were not stable, hence compromising generalizability of the model in the context of the study. It was recommended that, since Job Embeddedness Theory is a developing perspective, the volatile variables should be considered for revision or deletion in the future studies, before a seven-factor Job Embeddedness model is accepted for generalizability to larger population of academic members of staff in Tanzania's Universities.
\end{abstract}

Keywords: Academic Staff; Job Embeddedness; Exploratory Factor Analysis; Model Dimensionality; Cross Validation; Tanzania's Universities.

Cite This Article: Silver J. Hokororo, Ernest Kitindi, and Francis Michael. (2018). "ACADEMIC STAFF JOB EMBEDDEDNESS: MODEL DIMENSIONALITY AND VALIDATION IN TANZANIA'S UNIVERSITIES.” International Journal of Research - Granthaalayah, 6(9), 278290. https://doi.org/10.5281/zenodo.1443443.

\section{Introduction}

As retention of key employees become paramount in strategic management of organizations, researchers and practicing managers are finding it increasingly important to understand mechanisms that explain employee attachment in their jobs. Job embeddedness theory has opened up a new and promising perspective for understanding employee retention (Mitchell et al., 2001; Ping and Xi, 2013; Zhang et al., 2012). This perspective departs from traditional perspectives 
which assert that retention of employee is a result of the attitudes about one's present job together with the perceived availability of alternatives jobs (Watson, 2011). Job embeddedness theory associates employee retention with three influences termed fit, links and sacrifices, which are present on-the-job (organisational embeddedness) and also off-the-job (community embeddedness). These influences are compared to strands in a web or net in which a person can become stuck or bound from leaving the organization (Mitchell et al., 2001).

Job Embeddedness Theory has been tested in different cultural and occupational contexts, largely in America and Europe (Besich, 2010; Crossley et al., 2007), but scarcely tested in the context of Africa, in countries such as Cameroon (Karatepe and Ngeche, 2012), Egypt (Nafei, 2015), Ghana (Nicholas et al., 2016), Nigeria (Karatepe, 2013) and South Africa (Ferreira and Coetzee, 2013; Takawira and Coetzee, 2014; Van Dyke et al., 2013). In these studies, models with varied factor structures were found to appropriately explain job embeddedness in different contexts (Besich, 2005; Crossley et al., 2007; Mallol et al., 2007; Mitchell et al., 2001; Ramesh and Gelfand, 2010). It follows that, there has been no consensus on the generalizability of Job Embeddedness Model globally, including work organisations in the context of Africa. In Ramesh and Gelfand's (2010) words, even the most established findings on job embeddedness cannot be generalized across cultures without testing in the new context.

As the challenge of retaining academic staff in Africa's universities become critical (Tettey, 2010; Bernard 2012), studies that examine the promising perspectives of employee retention in unexplored contexts are warranted. The need for further understanding of academic staff retention is augmented by the fact that, it is difficult to replace the skills, knowledge and experience of academic staff once lost (Pienaar and Bester, 2008). While there is no evidence of an empirical study on job embeddedness in Tanzania, evidences of academic staff turnover (Nyahongo, 2015) and attitudes towards leaving (Mkumbo, 2014) indicate that, more need to be understood if universities are to improve their abilities to retain academic members. This study had two objectives; first, determining the model with factor structure that appropriately explains job embeddedness of academic staff in Tanzania's universities and; second, assessing how well the job embeddedness model can be generalized among academic staff in Tanzania's universities.

\section{Literature Review}

\section{Theoretical Perspective of Job Embeddedness}

Job embeddedness was originally developed as a six dimension model comprised of organisation fit, organisation link, organisation sacrifice, community fit, community link, and community sacrifice, which are created by a combination of three embedding forces (link, fit and sacrifice) within two settings (community and work organisation). According to Mitchell et al., (2001), Community Links are the social, psychological and financial ties an individual has with the family, friends, groups, institutions and environment in the community outside the work; Community Fit, is the perceived compatibility or comfort with the community and the environment such as weather, amenities, general culture, outdoor activities, political and religious activities, and entertainment, in the location where one resides; Community Sacrifices are the perceived cost of material or psychological benefits that may be forfeited by leaving one's community, including leaving a safe and attractive neighborhoods, leaving a society in which one is senior, loved and respected, and leaving an easy commute. 
Mitchell et al., (2001) also assert that, Organization Links are the formal and informal connections that an individual has with the organization such as departments and work-teams and with others at work such as co-workers, bosses and mentors; Organization Fit is the compatibility of an employee's personal values, career goals, and plan for future, with the corporate culture and demand of his or her immediate job, including job knowledge, skills and abilities; Organization Sacrifice are the perceived cost of material or psychological benefits that may be forfeited by organizational departure. These benefits may include personal losses such as giving up colleagues, relevant projects or pleasant perks, switching costs such as new health care, pension plans, due promotions, and sabbaticals.

Mitchell et al., (2001) considered job embeddedness at an aggregate level as a single factor. In this respect, average scores of the six dimensions were averaged (a mean of means) to obtain an aggregate score of job embeddedness. The findings of the study revealed a significant negative correlation between aggregate job embeddedness and turnover intention.

Stirred up by a spirit of extending the theory and research on employee retention, Lee et al. (2004) disaggregated job embeddedness construct into two of its sub-dimensions; on-the-job (organisation) embeddedness and off-the-job (community) embeddedness and tested how each of them separately predicted voluntary turnover. This disaggregation offered more insights on the way job embeddedness predicted employee turnover. In this study, the relationship between community embeddedness and turnover was significantly negative, while the relationship between organisation embeddedness and turnover was not significant. In a similar study, Allen (2006) revealed contrary results, where the relationship between community embeddedness and turnover was insignificant, while the relationship between organisation embeddedness and turnover was significantly negative. These contradictions indicate that certainly, the contextual appropriateness of Job Embeddedness Theory in terms of model's factor structure remains debatable. Mitchell et al. (2001) clearly emphasized that, though its tenets are well established, Job embeddedness is still a developing theory.

\section{Empirical Studies}

Further researches on dimensionality of job embeddedness have been conducted in different contexts and have come up with different propositions. Besich (2005) conducted a study in USA comparing the predictive power of the job embeddedness model against the traditional models of turnover. Job embeddedness model in this study comprised only on-the-job items. Data was collected from a sample of 2078 Information Technology workers in the Department of Veteran Affairs across the country and was analysed using structural equation modeling. Three models; traditional model, the embeddedness model, and a combined traditional-embeddedness model on turnover intention were tested. The findings of this study indicated that a five-factor model of job embeddedness alone was the best fit for the data in the study context. This study clearly supported the findings of Mitchell et al. (2001) concerning the improvement of turnover predictive power of embeddedness above and beyond the traditional model. However, unlike the original six-factor job embeddedness model, Besich (2005) found that in context of this study, job embeddedness was explained most appropriately by a five-factor model.

Robinson et al., (2014) conducted a study aiming at validating the factor structure of job embeddedness in hospitality industry in Australia. A survey was conducted with a sample of 327 
frontline hotel employees and data analysed by exploratory factor analysis, and confirmatory factor analysis using structural equation modeling software. Two job embeddedness models; a two-factor model and a six-factor model were compared, and the best solution was found to be a six-factor model. This factor solution conforms to the original six-factor proposition of Mitchell et al., (2001), emphasizing that each of the six dimensions is a distinct construct. It however, differs from a five-factor model proposed by Besich (2005) and three factor solution proposed by Toker and Çelik (2017).

A study was conducted by Toker and Çelik (2017) in Turkey to determine the factor structure of job embeddedness and its relationship with demographic characteristics of employees in hospitality industry. A survey was conducted to collect data from 210 employees in a five-star hotel and data analysed using Exploratory Factor Analysis (EFA), Analysis of Variance (ANOVA) and t-test. In this study, link dimension in both community and organization was not included in job embeddedness scale because its items were represented in demographic profile of respondents. The findings of EFA indicated that job embeddedness in the context of this study was represented as a three-factor model comprised of organization sacrifice, organization fit and community fit. The three-factor model in this study is contrary to a six-factor model proposed by Mitchell et al., (2001), indicating lack of consensus on the factor structure and hence generalizability of job embeddedness model.

The differing model's factor solutions reviewed above warrant further examination of the JE model before it can appropriately be used in predicting intention to stay and other organization outcomes in Tanzania's universities or different contexts.

\section{Materials and Methods}

\section{Participants}

A total of 314 academic members of staff were randomly selected from a population of 2373 in the five universities, which included two public universities; University of Dar es Salaam and University of Dodoma, and three private universities; Saint Augustine University of Tanzania, University of Iringa and Saint John University of Tanzania. This sample size was determined by the Krejcie and Morgan (1970) formula, and was sufficient for factor analysis in this study (Yong and Peace, 2013). The sample comprised 210 male and 104 female academic staff, $77.7 \%$ of which were below the age of 50 years, $34.1 \%$ had Doctorate degrees as their highest education qualification, and $39.5 \%$ were academic staff with senior ranks (lecturers, senior lecturers, associate professors and professors).

\section{Materials and Data Collection}

Structured questionnaire was used in data collection from subject academic members of staff. The questionnaire used comprised sections for demographic characteristics of respondents and items measuring job embeddedness. Job embeddedness scale was a 36 items customized version developed by Mitchell et al., (2001) which was adopted from a study of academic staff by Shafique et al., (2011). Items in job embeddedness scale described the six dimensions of a construct, and were scored using a five point Likert's scale ranging from $1=$ strongly disagree to $5=$ strongly agree. Before data collection, permission was sought by a letter from the University of Dar es Salaam where this study was hosted, to the Regional Commissioners of four regions of Dar es Salaam, Iringa, Dodoma and Mwanza, who introduced a researcher to the District Commissioners 
and Executive Directors of districts where selected universities were located. The later introduced the researcher to the Vice Chancellors of the five Universities where data were collected.

\section{Data Analysis}

Prior to main analysis, data were cleaned to remove outliers and missing values and then tested for normality, linearity and multicollinearity in order to conform to assumptions of multivariate analysis. Main data analysis, in objective one involved Exploratory Factor Analysis (EFA) in determining the appropriate factor structure of a JE model. Before EFA, Bartlett's test of Sphericity and Keiser-Meyer-Olkin (KMO) were used in order to determine adequacy of data for factor analysis. EFA with Principal Component Analysis (PCA) was used in factor extraction. PCA has advantage of summarizing the interrelationships among a set of original variables in terms of a smaller set of uncorrelated principle components (Sreejesh et al., 2014). For the most adequate interpretation of the variables an orthogonal rotation with Varimax solution was opted. Factor loading values $>.5$ indicated sufficient loading (Field, 2009) and communality value of .5 or above indicated that a variable shares sufficient of its variance with other variables (Hair, 2010).

Data analysis in objective two involved split sample validation to demonstrate how a model is a reasonable representation and can be generalized in explaining job embeddedness in the actual population. Split sample analysis was appropriate in this study because job embeddedness is a formative construct, hence the use of alternative techniques such as confirmative factor analysis was not feasible, or would require sophisticated programmes which were not accessible.

In split sample technique, a sample was randomly split into two equal samples with 157 respondents each, which satisfies a minimum sample size of 155 , representing five observations per each of 31 variables in this study as recommended by Hair (2010). Factor models were then re-estimated and compared for factor structures, factor loadings and communalities of variables. Generalizability is said to be supported when the values of factor loadings and communalities of the variables in the two split samples are reasonably stable. According to Osborne and Fitzpatrick (2012), rotated factor loading is considered volatile when the value of squared difference for congruent variables adds up to 0.04 , which indicates a difference of $|0.2|$. On the other hand, generalizability is compromised if the values of factor loadings and communalities of the variables in the two split samples are volatile. SPSS version 22 was used in both, exploratory factor analysis and cross validation.

\section{Results and Discussions}

Test for assumptions of multivariate analysis revealed presence of high skewness (non-normality) in one item of job embeddedness (My skills and abilities are well utilized in my job), which was then dropped and a model remained with 35 items. Missing values were replaced by multiple imputations technique, available in SPSS. Bartlett's Test of Sphericity was significant (4992.448; $\mathrm{p}<.001)$ and KMO was .877 , which is within a range of great values (0.8 to 0.9$)$, indicating that data sample size was suitable for factor analysis (Field, 2009).

\section{Factor Structure of Job Embeddedness Model}

Factor structure of a JE model was determined by EFA where all 35 items were included in the analysis. After analysis, two items (Benefits at this University are outstanding and There is 
excellent prospect for continuing employment in this University) were dropped from a model because of cross loadings, and 2 others (My coworkers respect me and I am respected by people in my community), because of low factor loadings (<.5) as recommended by (Hair, 2009). One more item (I would sacrifice a lot if I left this job) was dropped because of low communality (< $.5)$. The resultant model had 30 items grouped into seven components, which had eigenvalue over Kaiser's criterion of 1 . Table 1 presents the factor loadings of items, percentage variance explained by each component (after rotation) and reliability of scales as expressed by Cronbach's Alpha.

Table 1: Factor Structure, Variance Explained and Reliability of Job Embeddedness Model

\begin{tabular}{|c|c|c|c|c|}
\hline \multicolumn{2}{|c|}{ FactorItems } & \multirow{2}{*}{\begin{tabular}{|c|} 
Factor \\
Loadings
\end{tabular}} & \multicolumn{2}{|c|}{$\%$ Variance Cronbach's } \\
\hline & & & Explained & \\
\hline \multirow[t]{8}{*}{1} & I love the place where I live & .846 & \multirow[t]{8}{*}{15.835} & \multirow[t]{8}{*}{.896} \\
\hline & Climate of the place I live is suitable & .837 & & \\
\hline & I consider a community where I live as home & .834 & & \\
\hline & There is great sense of belonging to the house I live & .760 & & \\
\hline & There is family-oriented environment where I live & .741 & & \\
\hline & The area I live offers leisure activities I like & .639 & & \\
\hline & My neighborhood is safe & .577 & & \\
\hline & It is very hard leaving the community I live & .506 & & \\
\hline \multirow[t]{8}{*}{2} & I can reach professional goals in this University & .842 & \multirow[t]{8}{*}{15.462} & \multirow[t]{8}{*}{.879} \\
\hline & I am valued by the name of my University & .819 & & \\
\hline & $\begin{array}{l}\text { My values are compatible with the values of my } \\
\text { University }\end{array}$ & .775 & & \\
\hline & Good professional growth and development & .718 & & \\
\hline & Freedom to decide on how to pursue goals & .662 & & \\
\hline & Promotion opportunities are excellent & .643 & & \\
\hline & I like authority and responsibility in University & .548 & & \\
\hline & I like the culture of this university & .550 & & \\
\hline \multirow[t]{3}{*}{3} & I have saved in this profession for long time & .880 & \multirow[t]{3}{*}{8.209} & \multirow[t]{3}{*}{.843} \\
\hline & I have saved in this university long time & .844 & & \\
\hline & I have saved in this position for long time & .787 & & \\
\hline \multirow[t]{3}{*}{4} & Health benefits are excellent in this University & .758 & \multirow[t]{3}{*}{7.436} & \multirow[t]{3}{*}{.780} \\
\hline & Retirement benefit in this University are excellent & .748 & & \\
\hline & Well compensated by my performance & .664 & & \\
\hline \multirow[t]{3}{*}{5} & There is a number of family members nearby & .735 & \multirow[t]{3}{*}{7.105} & \multirow[t]{3}{*}{.725} \\
\hline & My family roots are in this community & .739 & & \\
\hline & I have a number of close friends living nearby & .642 & & \\
\hline \multirow[t]{3}{*}{6} & Many coworkers interact with me regularly & .712 & \multirow[t]{3}{*}{6.365} & \multirow[t]{3}{*}{.604} \\
\hline & I participate in many work teams/committees & .630 & & \\
\hline & Many coworkers highly depend upon me & .603 & & \\
\hline \multirow[t]{3}{*}{7} & My co-workers are similar to me & .729 & \multirow[t]{2}{*}{6.229} & \multirow[t]{2}{*}{.574} \\
\hline & I like the members of my work group & .669 & & \\
\hline & & Total & \multicolumn{2}{|l|}{66.642} \\
\hline
\end{tabular}


The results of EFA in Table 1 indicated that all items in the seven components were significant, with factor loading >.5 (Hair, 2009). Guided by the underpinnings of JE Theory, the components in our study were named; Community Fit (Factor 1), with 8 items which combine community fit and community sacrifice items in the original (priori) JE model (Mitchell et al., 2001); Organization Fit (Factor 2), with 8 items which combine some 7 items from organization fit and one item from organization sacrifice dimensions in the priori JE model; Organization Links (Factor 3), with all 3 items extracted from organization link dimension in a priori JE model; Organization Sacrifice (Factor 4), with all 4 items from organization sacrifice in a priori JE model; Community Links (Factor 5), with all 3 items from community link dimension in a priori JE model; Coworkers Links (Factor 6), with all 3 items extracted from organization links dimension in the priori JE mode; and Coworkers Fit (Factor 7), with all 2 items extracted from organization fit dimension in the priori JE model.

The findings also indicated that, a seven-factor model in our study explained a total of $66.6 \%$ of variance in Job Embeddedness, with the highest contribution coming from Organization Fit $(15.8 \%)$ and lowest contribution from Coworkers Fit (6.2\%). The scales measuring seven dimensions of job embeddedness had Cronbach's alpha ranging from the highest 0.896 for Community Fit to the lowest 0.574 for Coworkers Fit. According to Field (2009), the value even less than 0.7 are acceptable for Cronbach's alpha when dealing with psychological constructs. Furthermore, Pallant (2007) commended that, values as less as 0.5 are acceptable for the constructs with less than 10 items. The values of Cronbach's alpha in our study therefore indicated that scales for all dimensions in our JE model had sufficient reliabilities.

\section{Validation of Job Embeddedness Model}

Split sample estimation procedure was used in cross validation, in order to test generalizability of job embeddedness model in this study. The findings of analysis in Table $2 \mathrm{a}$ and Table $2 \mathrm{~b}$ present factor structures, factor loadings and communalities for split samples 1 and split sample 2 respectively.

Table 2a: Job Embeddedness Factor Structure, Factor Loadings and Communalities for SplitSample 1

\begin{tabular}{|c|c|c|c|c|c|c|}
\hline \multirow[t]{2}{*}{ Items } & \multicolumn{5}{|c|}{ Rotated Loadings in Factors } & \multirow[t]{2}{*}{ Communality } \\
\hline & \begin{tabular}{|l|l|}
1 & 2 \\
\end{tabular} & \begin{tabular}{|l|l|}
3 & 4
\end{tabular} & 5 & 6 & 7 & \\
\hline I love the place I live & .844 & & & & & .781 \\
\hline Climate of the place is suitable & .819 & & & & & .702 \\
\hline I consider the community I live as home & .824 & & & & & .776 \\
\hline Great sense of belonging to the house I live & .731 & & & & & .657 \\
\hline Family oriented environment where I live & .714 & & & & & .693 \\
\hline The area I live offer leisure activities I like & .604 & & & & & .646 \\
\hline My neighborhood is safe & .558 & & & & & .538 \\
\hline I can reach professional goals in this university & .820 & & & & & .737 \\
\hline $\begin{array}{l}\text { My values are compatible with values of my } \\
\text { university }\end{array}$ & .797 & & & & & .703 \\
\hline I am valued by the name of this University & .774 & & & & & .722 \\
\hline I like the culture of this university & .696 & & & & & .617 \\
\hline Good professional growth and development & .680 & & & & & .630 \\
\hline
\end{tabular}




\begin{tabular}{|c|c|c|c|c|c|c|c|}
\hline I am free to decide on how to pursue goals & & .581 & & & & & .504 \\
\hline I like authority and responsibility in university & & .580 & & & & & .506 \\
\hline Promotion opportunities are excellent & & .546 & & & .484 & & .599 \\
\hline I have saved in this profession for a long time & & & 884 & & & & .810 \\
\hline I have saved in this university for a long time & & & 867 & & & & .809 \\
\hline I have saved in this position for a long time & & & 821 & & & & .751 \\
\hline Health benefits are excellent in this university & & & & .718 & & & .704 \\
\hline Retirement benefit in this university are excellent & & & & .797 & & & .725 \\
\hline I am well compensated by my performance & & & & .677 & & & .683 \\
\hline My family roots is in this community & & & & & .782 & & .708 \\
\hline I have a number of family members nearby & & & & & .771 & & .712 \\
\hline A number of close friends lives nearby & & & & & .704 & & .587 \\
\hline It is very hard leaving the community where I live & 451 & & & & .467 & & .526 \\
\hline Participate in many work teams/committees & & & & & & .708 & .669 \\
\hline Many coworkers interact with me regularly & & & & & & .669 & .654 \\
\hline Many coworkers highly depend upon me & & & & & & .470 & .527 \\
\hline Co-workers are similar to me & & & & & & & .740 .602 \\
\hline I like the members of my work group & & & & & & & .675 .653 \\
\hline
\end{tabular}

Comparison of factor structure of job embeddedness models in split sample 1 (Table 2a) and split sample 2 (Table $2 \mathrm{~b}$ ) indicated that, both had seven factors, with variables loading in congruent factors for factor 2, factor 3, factor 6 and factor 7. It was also noted that, one variable, it is very hard leaving the community where I live, cross loaded in factor 1 and factor 5 in split sample 1, though its factor loading had almost similar magnitude to warrant assignment in any of the two factors. This variable and the six others namely, I like authority and responsibility in university, I like the culture of this university, health benefits are excellent in this university, I am well compensated by my performance, my family roots are in this community and there are number of family members living nearby, had loaded in incongruent factors in the two split samples.

Table 2b: Job Embeddedness Factor Structure, Factor Loadings and Communalities for SplitSample 2

\begin{tabular}{|c|c|c|c|c|c|c|c|}
\hline \multirow[t]{2}{*}{ Items } & \multicolumn{6}{|c|}{ Rotated Loadings in Factors } & \multirow[t]{2}{*}{ Communality } \\
\hline & 1 & 2 & \begin{tabular}{|l|l|}
3 & 4 \\
\end{tabular} & 5 & 6 & 7 & \\
\hline I Love the place I live & .852 & & & & & & .812 \\
\hline Climate of the place is suitable & .851 & & & & & & .756 \\
\hline I consider community I live as home & .845 & & & & & & .830 \\
\hline Great sense of belonging to the house I live & .779 & & & & & & .787 \\
\hline Family oriented environment where I live & .761 & & & & & & .715 \\
\hline The area offer leisure activities I like & .680 & & & & & & .636 \\
\hline My neighborhood is safe & .611 & & & & & & .567 \\
\hline It is very hard leaving the community I live & .550 & & & & & & .596 \\
\hline I can reach professional goals in this university & & .875 & & & & & .809 \\
\hline $\begin{array}{l}\text { My values are compatible with values of my } \\
\text { university }\end{array}$ & & .827 & & & & & .722 \\
\hline I am valued by the name of University & & .882 & & & & & .808 \\
\hline
\end{tabular}




\begin{tabular}{|c|c|c|c|c|c|c|}
\hline Promotion opportunities are excellent & .799 & & & & & .742 \\
\hline Good professional growth and development & .775 & & & & & .668 \\
\hline I am free to decide on how to pursue my goals & .640 & & & & & .540 \\
\hline Health benefits are excellent in this university & .552 & & .522 & & & .669 \\
\hline I am well compensated by my performance & .542 & & & & & 607 \\
\hline Saved in this profession for long time & & .817 & & & & .774 \\
\hline Saved in this university long time & & .811 & & & & .802 \\
\hline Saved in this position for long time & & .748 & & & & .653 \\
\hline My family roots are in this community & & & .655 & & & .720 \\
\hline Number of family members nearby & & & .645 & & & .672 \\
\hline Retirement benefit in this university are excellent & & & .513 & & & .616 \\
\hline I like authority and responsibility in university & & & & .745 & & .753 \\
\hline I like the culture of this university & & & & .643 & & .690 \\
\hline Number of close friends living nearby & & & & .610 & & .602 \\
\hline Participate in many work teams/committees & & & & & .533 & .626 \\
\hline Many coworkers interact with me regularly & & & & & .759 & .737 \\
\hline Many coworkers highly depend upon me & & & & & .769 & .731 \\
\hline Co-workers are similar to me & & & & & & .626 .661 \\
\hline I like the members of my work group & & & & & & \begin{tabular}{|l|l|l|}
.852 & .763 \\
\end{tabular} \\
\hline
\end{tabular}

Comparison of magnitudes of factor loadings of variables in the two samples is presented by the values of their squared differences in Table 3.

Table 3: Job Embeddedness Model's Factor Loadings, Communalities and Factor Loading Squared Difference for the Two Samples

\begin{tabular}{|l|c|c|c|c|c|}
\hline Variables & \multicolumn{2}{|c|}{ Sample 1 } & \multicolumn{2}{c|}{ Sample 2 } & Squared \\
\cline { 2 - 5 } & $\begin{array}{c}\text { Factor } \\
\text { Loading }\end{array}$ & Communality & $\begin{array}{c}\text { Factor } \\
\text { Loading }\end{array}$ & Communality & Difference \\
\hline $\begin{array}{l}\text { I love the place I live } \\
\begin{array}{l}\text { Climate of the place is } \\
\text { Suitable }\end{array}\end{array}$ & .844 & .781 & .852 & .812 & .000064 \\
\hline $\begin{array}{l}\text { I consider the community I } \\
\text { live as home }\end{array}$ & .824 & .702 & .851 & .756 & .001024 \\
\hline $\begin{array}{l}\text { Great sense of belonging to } \\
\text { the house I live }\end{array}$ & .731 & .657 & .779 & .787 & .002304 \\
\hline $\begin{array}{l}\text { Family oriented environment } \\
\text { where I live }\end{array}$ & .714 & .693 & .761 & .715 & .002209 \\
\hline $\begin{array}{l}\text { The area I live offer leisure } \\
\text { activities I like }\end{array}$ & .604 & .646 & .680 & .636 & .005776 \\
\hline $\begin{array}{l}\text { My neighborhood is safe } \\
\text { It is very hard leaving the } \\
\text { community where I live }\end{array}$ & .558 & .538 & .611 & .567 & .002809 \\
\hline $\begin{array}{l}\text { I can reach professional goals } \\
\text { in this university }\end{array}$ & .820 & .737 & .875 & .809 & Incongruent \\
\hline
\end{tabular}




\begin{tabular}{|c|c|c|c|c|c|}
\hline $\begin{array}{l}\text { My values are compatible } \\
\text { with values of my university }\end{array}$ & .797 & .703 & .827 & .722 & .0009 \\
\hline $\begin{array}{l}\text { I am valued by the name of } \\
\text { this University }\end{array}$ & .774 & .722 & .882 & .808 & .011664 \\
\hline $\begin{array}{l}\text { I like the culture of this } \\
\text { university }\end{array}$ & .696 & .617 & .643 & .690 & .000289 \\
\hline $\begin{array}{l}\text { Good professional growth } \\
\text { and development }\end{array}$ & .680 & .630 & .775 & .668 & .009025 \\
\hline $\begin{array}{l}\text { I am free to decide on how to } \\
\text { pursue goals }\end{array}$ & .581 & .504 & .640 & .540 & .003481 \\
\hline $\begin{array}{l}\text { I like authority and } \\
\text { responsibility I have }\end{array}$ & .580 & .506 & .745 & .753 & .027225 \\
\hline $\begin{array}{l}\text { Promotion opportunities are } \\
\text { excellent }\end{array}$ & .546 & .599 & .799 & .742 & .064009 \\
\hline $\begin{array}{l}\text { I have saved in this } \\
\text { profession for a long time }\end{array}$ & .884 & .810 & .817 & .774 & .004489 \\
\hline $\begin{array}{l}\text { I have saved in this } \\
\text { university for a long time }\end{array}$ & .867 & .809 & .811 & .802 & .003136 \\
\hline $\begin{array}{l}\text { I have saved in this position } \\
\text { for a long time }\end{array}$ & .821 & .751 & .748 & .653 & .005329 \\
\hline $\begin{array}{l}\text { Health benefits are excellent } \\
\text { in this university }\end{array}$ & .718 & .704 & .552 & .669 & Incongruent \\
\hline $\begin{array}{l}\text { Retirement benefit in this } \\
\text { university are excellent }\end{array}$ & .797 & .725 & .513 & .616 & .080656 \\
\hline $\begin{array}{l}\text { I am well compensated by } \\
\text { my performance }\end{array}$ & .677 & .683 & .542 & .607 & Incongruent \\
\hline $\begin{array}{l}\text { My family roots is in this } \\
\text { community }\end{array}$ & .782 & .708 & .655 & .720 & Incongruent \\
\hline $\begin{array}{l}\text { I have a number of family } \\
\text { members nearby }\end{array}$ & .771 & .712 & .645 & .672 & .015876 \\
\hline $\begin{array}{l}\text { A number of close friends } \\
\text { lives nearby }\end{array}$ & .704 & .587 & .610 & .602 & Incongruent \\
\hline $\begin{array}{l}\text { Participate in many work } \\
\text { teams/committees }\end{array}$ & .708 & .669 & .533 & .626 & .030625 \\
\hline $\begin{array}{l}\text { Many coworkers interact } \\
\text { with me regularly }\end{array}$ & .669 & .654 & .759 & .737 & .0081 \\
\hline $\begin{array}{l}\text { Many coworkers highly } \\
\text { depend upon me }\end{array}$ & .470 & .527 & .769 & .731 & .089401 \\
\hline Co-workers are similar to me & .740 & .602 & .626 & .661 & .012996 \\
\hline $\begin{array}{l}\text { I like the members of my } \\
\text { work group }\end{array}$ & .675 & .653 & .852 & .763 & .031329 \\
\hline
\end{tabular}

The result in Table 3 indicates that, with exception of three variables, promotion opportunities are excellent, retirement benefit in this university are excellent and many coworkers highly depend upon me, all variables which loaded in the congruent factors in the two samples had values of squared difference of factor loadings, of less than 0.04, indicating that they were sufficiently stable. 


\section{Conclusions and Recommendations}

From the results of this study, it is concluded that job embeddedness in the context of academic staff in Tanzania's universities is a seven factors model. Based on the theory, the factors were named; Community Fit, Organization Fit, Organization Sacrifice, Organization Links, Community Links, Coworkers Links, and Coworkers Fit. The significant role of coworkers in job embeddedness of academic staff in the context of this study has been expressed by formation of distinct factors for its links and fit dimensions. The nature of academic work requires a lot of team working and collaboration with coworkers. On the other hand, community sacrifice did not stand as a factor in this study reflecting the nature of academic work that requires academic staff to be away from their community most of the time, hence less perceived cost of material or psychological benefits that may be forfeited by leaving one's community. This model as a whole explained sufficient variance in Job Embeddedness, and all its factors had sufficient reliabilities. Majority of variables in the model had stable and roughly equivalent magnitude of factor loadings in the split samples.

From the results of the study however, it was revealed that seven of the model's variables did not load in the congruent factors in the two sub-samples, and three other variables of those which loaded in the congruent factors had significant different factor loadings in the two analyses. This indicated that these variables were volatile and hence subject to change in different samples. Since Job Embeddedness Theory is still a developing theory, it is recommended that, the volatile variables should be considered for revision or deletion in the future studies, before a seven factor Job Embeddedness model is accepted for generalizability in the wider population of this study or samples in other populations in Tanzania's context.

\section{Acknowledgements}

This study was part of a PhD research. The sponsor of the study, the World Bank, Science and Technology Higher Education Project (STHEP) in Tanzania, is highly acknowledged.

\section{References}

[1] Allen, D. (2006). "Do Organizational Socialization Tactics Influence Newcomers Embeddedness and Turnover?" Journal of Management, 32(2), 237-256. http://jom.sagepub.com/cgi/content/abstract/32/2/237.

[2] Bernard, B. (2012). "Factors that Determine Academic Staff Retention and Commitment in Private Tertiary Institutions in Botswana: Empirical Review". Global Advanced Research Journal of Management and Business Studies, 1(9), 278-299. http://garj.org/garjbb/index.htm.

[3] Besich, J. (2005). Job Embeddedness versus Traditional Models of Voluntary Turnover: A Test of Voluntary Turnover Prediction. Unpublished PhD Thesis, University of North Texas.

[4] Crossley, C., Bennett, R., Jex. S. and Burnfield, J. (2007). "Development of Global Measure of Job Embeddedness and Integration into a Traditional Model of Voluntary Turnover, Management Department Faculty Publication", Paper 34, University of Nebraska-Lincoln. http://digitalcommons.unl.edu/managementfacpub/34.

[5] Ferreira, N. and Coetzee, M. (2013). "The Influence of Job Embeddedness on Black Employees' Organizational Commitment". Southern African Business Review, 17(3), 239-255. https://www.ajol.info/index.php/sabr/article/download/110935/100694. 
[6] Field, A. (2009). Discovering Statistics Using SPSS, ( $3^{\text {rd }}$ ed.). London, California, Sage Publications Ltd. 627-682.

[7] Hair, F., Black, W., Babin, B. and Anderson, R. (2010). Multivariate Data Analysis, ( $7^{\text {th }}$ ed.). Upper Saddle River, Pearson Prentice Hall, 90-147.

[8] Karatepe, O. (2013). "Inking Perceived Ethical Climate to Performance Outcome: The Mediating Role of Job Embeddedness". Economic Research, 26 (4) 77-90, https://www.researchgate.net/.../283930476.

[9] Karatepe, O. and Ngeche, R. (2012). "Does Job Embeddedness Mediate the Effect of Work Engagement on Job Outcomes? A study of Hotel Employees in Cameroon". Journal of Hospitality Marketing and Management, 21, (4), 440-461. http://dx.doi.org/10.1080/19368623.2012.626730.

[10] Krejcie, R. and Morgan, D. (1970). "Determining Sample Size for Research Activities", Education and Psychological Measurement, 30, 607-610. https://home.kku.ac.th/sompong/guest_speaker/KrejcieandMorgan_article.pdf.

[11] Lee, T., Mitchell, T., Sablynski, C., Burton, J. and Holtom, B. (2004). "Effect of Job Embeddedness on Organizational Citizenship, Job Performance, Volitional Absences, and Voluntary Turnover". Academy of Management Journal, 47(5), 711-722. https://www.jstor.org/stable/20159613.

[12] Mallol, C. Holtom, B. and Lee, T. (2007). "Job Embeddedness in Culturally Diverse Environment". Journal of Business Psychology, 22(1), 35-44. https://www.researchgate.net/.../211390618.

[13] Mitchell, T., Holtom, B., Lee, T., Sablynski, C. and Erez, M. (2001). "Why People Stay: Using Job Embeddedness to Predict Voluntary Turnover". Academy of Management Journal, 44, 1102-1121.

[14] Mkumbo, K. (2014). "Prevalence of and Factors Associated with Work Stress in Academia in Tanzania". International Journal of Higher Education, 3(1), 1-11.

[15] Nafei, W. 2015. "The Effects of Job Embeddedness on Organizational Cynicism and Employee Performance: A Study on Sadat City University". International Journal of Business Administration, 6 (1) 8-25. http://dx.doi.org/10.5430/ijba.v6n1p8.

[16] Nicholas, A., Mensah, A. and Owusu, N. (2016). "Stay or Leave? Using Job Embeddedness to Explain Turnover Intention among Hotel Staff in Ghana". Journal of Management Research, 8 (3), 123-139.

[17] Nyahongo, J. (2015). Improving Socio-Economic Environment to Promote Academic Staff Retention in Tanzanian Universities: Case Study of the University of Dodoma, in Managing Change at Universities-A selection of Case Studies from Africa and Southern Asia, Volume II, Edited by Peter Meyer and Marc Wilde.

[18] Osborne, J. and Fitzpatrick, D. (2012). Replication Analysis in Exploratory Factor Analysis: What it is and Why it Makes Your Analysis Better? Practical Assessment. Research and Evaluation, 17(15), 1-8.

[19] Pallant, J. (2007). SPSS Survival Manual: A Step by Strep Gide to Data Analysis Using SPSS for Windows (version 15), Allen and Unwin, 95.

[20] Pienaar, C. and Bester, C. (2008). "Retention of Academics in the Early Career Phase". SA Journal of Human Resource management, 6(2), 32-41. http://www.sajhrm.co.za.

[21] Ping, W. and Xi, Y. A (2013). "Review of Job Embeddedness: Conceptual, Measurement, and Relative Study Conclusions". International Academic Workshop on Social Science, 353-357. https://download.atlantis-press.com/article/9360.pdf.

[22] Ramesh, A. and Gelfand, M. (2010). "Will they Stay or Will they Go? The Role of Job Embeddedness in Predicting Turnover in Individualistic and Collectivistic Cultures". Journal of Applied Psychology, 95(5), 807-823. https://www.ncbi.nlm.nih.gov/pubmed/20836585.

[23] Robinson, R., Kralg, A., Solnet, D., Goh, E., and Callan, V. (2014). "Thinking Job Embeddedness, not Turnover: Towards a better understanding of Frontline Hotel Worker Retention". International Journal of Hospitality Management, 36, 101-109. https://core.ac.uk/download/pdf/143864425.pdf.

[24] Shafique, M., Qadeer, F., Ahman, M. and Rehman, R. (2011). Impact of Job Embeddedness on Leave Intention: An Understanding from Higher Education System". African Journal of Business Management, 5(30), 11794-11801. http://www.academicjournals.org/AJBM. 
[25] Sreejesh, S., Mohapatra, S. and Anusree, M. (2014). Business Research Methods: An Applied Orientation. Heidelberg, New York, London, 217.

[26] Takawira, N., Coetzee, M. and Schreuder, D. (2014). "Job Embeddedness, Work Engagement and Turnover Intention of Staff in Higher Education Institutions: An Exploratory Study". SA Journal of Human Resource Management, 12(1), 1-10. https://sajhrm.co.za/index.php/sajhrm/article/view/524/743.

[27] Toker, B. and Çelik, S. (2017). Job Embeddedness among Hospitality Industry Employees: An Empirical Study in Alanya". Anadolu University Journal of Social Sciences, 17 (3), 73-86. https://www.researchgate.net/.../292736044.

[28] Tettey, W. (2010). Challenges of Developing and Retaining the next Generation of Academicians: Deficit in Academic Staff Capacity at African Universities, Study Commissioned by the Partnership for Higher Education in Africa. www.foundationpartnership.org/pubs/pdf/tettey_deficits.pdf.

[29] Van Dyke, J., Coetzee, M., and Takawira, N. (2013). "Satisfaction with Retention Factors as Predictors of the Job Embeddedness of Medical and Information Technology Services Staff". Southern African Business Review, 17(1), 57-75. https://www.ajol.info/index.php/sabr/article/viewFile/110880/100636.

[30] Watson, J. (2011). Can Job Embeddedness Help Predict Novice Teacher Retention? Unpublished $\mathrm{PhD}$ Thesis, California State University. https://pqdtopen.proquest.com/doc/876180826.

[31] Yong, A. and Pearce, S. A. (2013). “Beginners' Guide to Factor Analysis: Focusing on Exploratory Factor Analysis", Tutorials in Quantitative Methods for Psychology, 9(2) 79-94. www.tqmp.org/RegularArticles/vol09-2/p079/p079.

[32] Zhang, M., Fried, D. and Griffeth, R. (2012). "A Review of Job Embeddedness: Conceptual, Measurement Issues, and Directions for Future Research". Human Resource Management Review, 22, 220-231. download.xuebalib.com/xuebalib.com.19425.

*Corresponding author.

E-mail address: silverhoko@ sua.ac.tz 